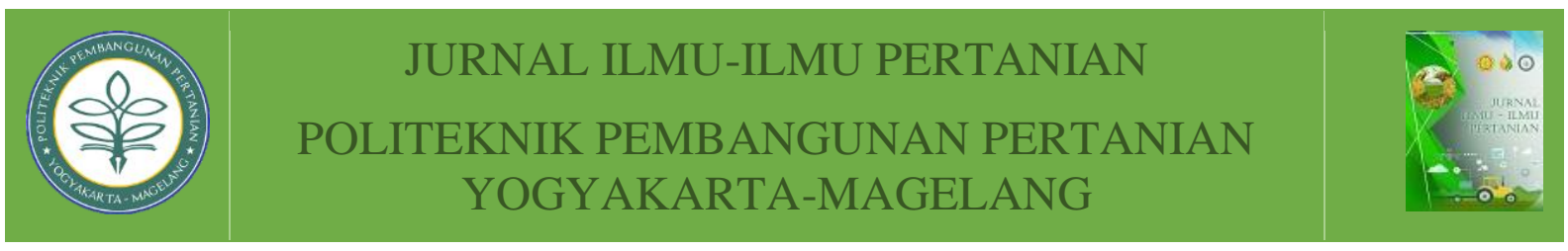

\title{
POTENSI PENGEMBANGAN JAHE Zingiber officinale DI KECAMATAN PRAMBANAN, KABUPATEN SLEMAN, DAERAH ISTIMEWA YOGYAKARTA
}

\author{
Sukadi $^{1}$, Galuh Hangganingraras Eko Akoso ${ }^{2}$, Heriyanto $^{3}$, Sevi Melati ${ }^{4}$ \\ ${ }^{1}$ Politeknik Pembangunan Pertanian Yogyakarta Magelang, Yogyakarta, 55167 \\ ${ }^{2}$ Politeknik Pembangunan Pertanian Yogyakarta Magelang, Yogyakarta, 55167 \\ ${ }^{3}$ Politeknik Pembangunan Pertanian Yogyakarta Magelang, Yogyakarta, 55167 \\ ${ }^{4}$ Politeknik Pembangunan Pertanian Yogyakarta Magelang, Yogyakarta, 55167
}

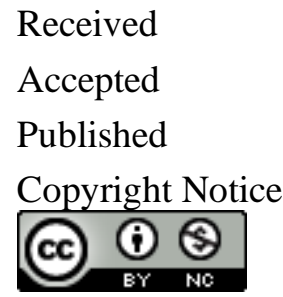

$$
\begin{array}{ll}
: & \text { February } 26^{\text {th }}, 2021 \\
: & \text { April } 16^{\text {th }}, 2021 \\
: & \text { June } 17^{\text {th }}, 2021
\end{array}
$$

: Authors retain copyright and grant the journal right of first publication with This work is licensed under a Creative Commons Attribution-Non Commercial 4.0 International License.

ABSTRAK: Penelitian ini bertujuan untuk mengetahui mengetahui jenis OPT pada budidaya jahe, cara pengolahan jahe, pemasaran jahe, dan model pemberdayaan petani jahe. Penelitian di Kec. Prambanan, Kab. Sleman, penelitian dilaksanakan pada bulan Maret s/d Desember 2019, jenis penelitian kualitatif didukung kuantitatif, jenis data primer, teknik sampling menggunakan purposive sampling, Teknik Pengumpulan Data kuesioner dan wawancara, hasil penelitian menunjukan bahwa: (1) Hama yang menyerang lalat rimpang (Mimegrala coeruleifrons), hama kepik (Epilahra sp.) dan penyakit yang menyerang busuk akar rimpang (Fusarium oxysporum) Penyakit layu bakteri, (2) Pengolahan hasil jahe yang sudah dilakukan petani $60 \%$ belum dilakukan pengolahan, (3) Pemasaran jahe yang sudah dilakukan petani $56.7 \%$ dipasarkan di pasar tradisional, (4) Pengembangan SDM petani $70 \%$ melalui penyuluhan (SL dan Pertemuan) penelitian melalui pengamatan budidaya jahe di Kecamatan Prambanan dapat dikembangkan.

Kata Kunci : Potensi, Jahe di Kecamatan Prambanan.

ABSTRACT: This study aims to determine the types of OPT in ginger cultivation, ginger processing methods, ginger marketing, and ginger farmer empowerment models. Research in the district. Prambanan, Kab. Sleman, the research was conducted from March to December 2019 , the type of qualitative research was supported by quantitative, primary data types, the sampling technique used purposive sampling, questionnaire and interview data collection techniques, the results of the study showed that: (1) Pests that attack rhizome flies ( Mimegralla coeruleifrons), ladybugs (Epilahra sp.) And diseases that attack rhizome root rot (Fusarium oxysporum) Bacterial wilt disease, (2) $60 \%$ processing of ginger products has not been processed, (3) Marketing of ginger that has been carried out $56.7 \%$ of farmers are marketed in 
traditional markets, (4) Development of human resources for farmers $70 \%$ through extension (FFS and meetings) research through observation of ginger cultivation in Prambanan District can be developed.

Keywords : Potential, Ginger in Prambanan District.

\section{PENDAHULUAN}

Pertanian memiliki peranan yang sangat penting dan strategis dalam pembangunan nasional maupun regional. Peranannya tidak hanya terhadap ketahanan pangan tetapi juga menjadi penarik bagi pertumbuhan industri hulu dan pendorong pertumbuhan industri hilir, yang kontribusinya cukup besar pada pertumbuhan. Disamping itu sub sektor pertanian dan peternakan juga berperan penting dalam penyediaan lapangan kerja, konservasi dan pelestarian sumber daya alam, pengentasan kemiskinan, memelihara nilai-nilai sosial dan lembaga pedesaan serta pelestarian lingkungan (Dinas Pertanian, Pangan dan Perikanan Kabupaten Sleman, 2018).

Kecamatan prambanan memiliki karakteristik tanah sebagai berikut jenis tanah Latosol (tekstur lempung) dan Regosol (tekstur lempung berpasir), keasaman tanah $(\mathrm{pH}) 5,5-7,0$, kemiringan dataran $0-20 \%$, ketinggian tempat $151-$ $360 \mathrm{~m}$ dpl, bulan basah rata-rata $6-8$ bulan, drainase tadah hujan $-1 / 2$ teknis, data tanah asal pelapukan batuan (Dinas Pertanian, Pangan dan Perikanan Kabupaten Sleman, 2018).

Kecamatan Prambanan berdasarkan penggunaan lahan sawah 3.137,32 ha, tegal $1.096,36$ ha, pekarangan 1.830,91 ha, lainlain 1.491,28 ha, jumlah keseluruhan $7.555,87$ ha. Jumlah penduduk sebanyak 132.140 jiwa terdiri atas 65.757 jiwa pria dan 66.383 jiwa wanita. Jumlah penduduk menurut pendidikan SD 37.829 orang, SLTP 24.343 orang, SLTA 35.219 orang, D-3 sampai S3 sebanyak 5.165 orang. Jumlah penduduk menurut pekerjaan petani 29.461 orang, PNS/ASN 9.879 orang, Swasta/Buruh 18.557 orang, lain-lain
10.953 orang, jumlah keseluruhan 68.450 orang (Dinas Pertanian, Pangan dan Perikanan Kabupaten Sleman, 2017).

Kecamatan Prambanan mempunyai luas tanaman jahe terluas di bandingkan dengan kecamatan lain yaitu sebesar 203 ha dengan produksi 4033 ton, kemudian kecamatan kalasan seluas 11,98 ha dengan produksi 248,9 ton dan kecamatan turi seluas 3,2 ha dengan produksi 64,5 ton (BPS, 2019). Dari uraian tersebut maka rumusan masalah apa saja jenis OPT pada budidaya jahe, bagaimana cara pengolahan jahe, bagaimana, pemasaran jahe, dan bagaimana model pemberdayaan petani jahe. Tujuan untuk mengetahui mengetahui jenis OPT pada budidaya jahe, cara pengolahan jahe, pemasaran jahe, dan model pemberdayaan petani jahe.

Jahe merupakan tanaman obat berupa tumbuhan rumpun berbatang semu. Jahe berasal dari Asia Pasifik yang tersebar dari India sampai Cina. Oleh karena itu kedua bangsa ini disebut-sebut sebagai bangsa yang pertama kali memanfaatkan jahe terutama sebagai bahan minuman, bumbu masak dan obat-obatan tradisional. Jahe termasuk dalam suku temu-temuan (Zingiberaceae) (Muharjoa, 2019).

Lebih dari 20.000 jenis tumbuhan obat tumbuh dan berkembang di Indonesia, namun baru 1.00 jenis saja yang sudah didata dan sekitar 300 jenis yang sudah dimanfaatkan untuk pengobatan tradisional. Penggunaan tumbuhan obat di Indonesia sebenarnya telah dimulai dari zaman nenek moyang bangsa Indonesia (Hariana, 2015).

Kecenderungan gaya hidup kembali ke alam (back to nature) mendorong masyarakat untuk memberi perhatian kembali kepada ramuan tradisional, sebagai 
alternatif dalam menjaga stamina tubuh maupun alternatif pengobatan secara alami . Jahe adalah salah satu tanaman rimpang yang dipergunakan secara luas di Indonesia, baik sebagai bumbu, ataupun dimanfaatkan karena memiliki khasiat obat.

Jahe umumnya digunakan sebagai tanaman obat ataupun biofarmaka oleh pengusaha jamu tradisional atau industri farmasi. Tiga jenis jahe yang dihasilkan di Indonesia adalah jahe emprit, jahe gajah, dan jahe merah. Hingga saat ini, permintaan pasar belum diimbangi dengan kemampuan petani untuk menghasilkan dalam jumlah besar (Kontan, 2016).

Kemampuan petani untuk memenuhi permintaan pasar dimulai dari proses budidaya di lahan. Aktivitas yang dimulai dari pemilihan bibit, pengolahan tanah, perawatan tanaman hingga pada akhirnya panen akan mempengaruhi besarnya hasil produksi. Persoalan teknis yang terjadi adalah serangan penyakit jamur pada daun tanaman jahe yang menyebabkan daun rusak kemudian menguning, mengakibatkan produktivitas menurun.

Pemasaran yang dilakukan adalah ke tengkulak/pengepul bentuk rimpang basah. Pengolahan jahe dalam bentuk jahe instan, kunir instan, kencur instan, temulawak instan, dipasarkan pada saat ada pameranpameran serta digunakan pada saat rapatrapat di kantor desa sebagai minuman pada saat rapat. Jejaring yang baik dalam pemasaran diperlukan untuk memastikan bahwa ketika melakukan budidaya jahe, petani telah mengetahui dengan pasti pembeli/penampung hasil produksi mereka.

Jahe umumnya dipasarkan dalam kondisi segar/belum diolah. Namun demikian, upaya pengolahan lebih lanjut akan dapat meningkatkan nilai tambah produk, dengan harapkan akan meningkatkan nilai jual. Untuk meningkatkan nilai tambah jahe, dilakukan penelitian untuk menemukan inovasi terhadap produk jahe segar.
Pengembangan SDM petani jahe dilakukan dengan penyuluhan tentang metode, update informasi terkait potensi jahe sangat membantu untuk terus memotivasi dan meningkatkan keterampilan petani jahe.

\section{METODE}

Penelitian dilakukan pada bulan Maret s/d Oktober 2019 sampai bertempat di Kecamatan Prambanan, Kabupaten Sleman, Daerah Istimewa Yogyakarta. Pemilihan lokasi penelitian dilakukan secara purposive di Kecamatan Prambanan memiliki luas tanam jahe paling luas di antara beberapa kecamatan di kabupaten sleman.

Penelitian ini menggunakan pendekatan kualitatif yang didukung dengan data kuantitatif. Pendekatan kualitatif digunakan karena mampu memberikan pemahaman secara mendalam tentang suatu realitas di dalam masyarakat. Realitas disini terkait potensi pengembangan jahe di Kecamatan Prambanan.

Menurut Denzin dan Lincoln (1994). pendekatan kualitatif menekankan pada proses-proses dan makna-makna yang tidak diuji atau diukur secara ketat dari segi uji variabel terkait kuantitas, intensitas, atau frekuensi. Fokus penelitian ini adalah potensi pengembangan jahe di Kecamatan Prambanan, Kabupaten Sleman.

Data yang dibutuhkan dalam penelitian ini adalah data primer dari informan petani yang membudidayakan jahe, perangkat desa setempat dan Penyuluh Pertanian Lapangan (PPL) dan Koordinator Penyuluh Pertanian Kecamatan prambanan, dan didukung oleh data sekunder dari BPS, BP3K, Kecamatan, Desa, dan lainnya.

Subjek dalam penelitian ini adalah petani yang membudidayakan jahe, perangkat desa setempat dan Penyuluh Pertanian Lapangan (PPL) dan Koordinator Penyuluh Pertanian Kecamatan Prambanan, Kabupaten Sleman. Snowball 
sampling adalah teknik pengambilan sampel berdasar sumber data, yang pada awalnya jumlahnya sedikit, lama-lama menjadi besar. Hal ini dilakukan karena dari jumlah sumber data yang sedikit tersebut belum mampu memberikan data yang memuaskan, maka mencari orang lain lagi yang dapat digunakan sebagai sumber data. Dengan demikian jumlah sampel sumber data akan semakin besar (Sugiyono, 2009).

Untuk memperoleh data dalam penelitian ini dilakukan melalui wawancara terutama untuk mengkaji potensi pengembangan jahe di Kecamatan Prambanan, Kabupaten Sleman. Tujuan dari wawancara jenis ini adalah untuk menemukan potensi pengembangan jahe di mana pihak yang diwawancarai dimintai pendapatnya. Dalam melakukan wawancara peneliti perlu mendengarkan secara teliti dan mencatat apa yang dilakukan informan (Sugiyono, 2009).

Uji keabsahan dan validitas data ditujukan untuk menguji apakah data yang diperoleh benar-benar sesuai dengan kondisi di lapangan atau kondisi yang sesungguhnya. Pada penelitian kualitatif menurut Sugiyono (2009) uji validitas data dapat dilakukan dengan triangulasi data yaitu menggabungkan dari berbagai teknik pengumpulan data dan sumber data yang telah ada, bisa dilakukan dengan menggunakan teknik yang berbeda-beda untuk mendapatkan data dari sumber data yang sama atau untuk mendapatkan data dari sumber yang berbeda-beda dengan teknik yang sama. Pengumpulan data dengan triangulasi juga sekaligus menguji kredibilitas data.

Menurut Miles and Huberman (1984), mengemukakan bahwa aktivitas dalam analisis data kualitatif dilakukan secara interaktif dan terus menerus sampai tuntas, sehingga datanya sudah jenuh. Tahapan dalam analisis data yaitu data reduction, data display dan conclusion/verification.

Reduksi data adalah memilih, menyederhanakan, mengabstraksi dan mentransformasi data kasar yang baru diperoleh dari lapangan. Reduksi data dan penyajian hasilnya dilakukan terus menerus selama pengumpulan data berlangsung, kemudian ditarik kesimpulan sementara. Jika pada penyajian masih terdapat kejanggalan-kejanggalan segera dilakukan reduksi melalui verifikasi (misalnya mencocokkan data data yang ada) atau mencari yang baru.

Penyajian data dalam tabel dalam tahap analisis masih untuk kepentingan peneliti sendiri, sifatnya disajikan sementara. Jika data belum dapat disimpulkan, maka data tersebut direduksi kembali dengan menguji kebenaran dan mencocokkan data yang lain untuk diperbaiki.

Penarikan kesimpulan atau verifikasi, penarikan kesimpulan dan verifikasi dilakukan secara terus menerus, pada awalnya berupa kesimpulan sementara, jika belum jelas dan masih terdapat kejanggalan, diadakan reduksi, verifikasi.

HASIL DAN PEMBAHASAN

Umur Responden (Petani Jahe)

Tabel 1. Distribusi Frekuensi Umur Responden.

\begin{tabular}{llcc}
\hline & & Frequency & Percent \\
\hline Valid & $\leq 40$ & 3 & 10.0 \\
& $40-55$ & 14 & 46.7 \\
& $\geq 55$ & 13 & 43.3 \\
& Total & 30 & 100.0 \\
\hline
\end{tabular}


Sebagian besar responden 46,7 \% berumur antara 40-55 tahun, menurut Departemen Kesehatan RI (2009) masuk kategori masa dewasa akhir 36-45 tahun dan masa lansia awal 46-55 tahun, ini berarti bahwa petani/responden petani jahe di Kecamatan prambanan masih efektif dalam mengembangan usaha pengembangan jahe hal ini sejalan dengan pendapat (Soekartawi, 1988) difusi inovasi yang paling tinggi adalah pada mereka yang berumur setengah tua. ini menunjukkan bahwa usia dimaksud akan mendukung kegiatan dan pengembangan usaha jahe di Kecamatan Prambanan.

Pendidikan Responden (Petani Jahe)

Tabel 2. Distribusi Frekuensi Tingkat Pendidikan Responden.

\begin{tabular}{llcc}
\hline & & Frequency & Percent \\
\hline Valid & SD & 13 & 43.3 \\
& SMP & 11 & 36.7 \\
& SMA & 6 & 20 \\
& S1 & - & - \\
& Total & 30 & 100.0 \\
\hline
\end{tabular}

Sebagian besar responden 43,3\% tingkat pendidikan Sekolah Dasar (SD), hal ini menunjukkan bahwa tingkat pendidikan. Soekartawi (2005) Menyatakan bahwa yang berpendidikan rendah sulit menerima pelaksanaan adopsi inovasi dengan cepat. Pendidikan sebagai sarana meningkatkan pengetahuan tentang teknologi pertanian baru bukan sesuatu hal baru.

Pengalaman Responden (Petani Jahe)

Tabel 3. Distribusi Frekuensi Pengalaman Responden.

\begin{tabular}{cccc}
\hline & & Frequency & Percent \\
\hline Valid & $<5$ tahun & 19 & 63.3 \\
& 6 s/d 10 tahun & 10 & 33.3 \\
& $>11$ tahun & 1 & 3.3 \\
& Total & 30 & 100.0 \\
\hline
\end{tabular}

Sebagian besar responden $63.3 \%$ mempunyai pengalaman usaha jahe kurang dari 5 tahun, ini menunjukan bahwa Usaha jahe cukup lama. Pendapat (Kasup dalam Kirana 2007) pengambilan suatu keputusan tentang berbagai masalah, seseorang sangat dipengaruhi oleh pengalaman-pengalaman di masa lampu, kecakapan dan asumsi mengenai situasi tertentu.

Luas lahan

Tabel 4. Distribusi Frekuensi luas lahan Responden

\begin{tabular}{llcc}
\hline & Frequency & Percent \\
\hline Valid & $<500 \mathrm{~m} 2$ & 24 & 80.0 \\
& $501-1000 \mathrm{~m} 2$ & 4 & 13.3 \\
& $>1001$ & 2 & 6.7 \\
& Total & 30 & 100.0 \\
\hline
\end{tabular}


Sebagian besar responden $80 \%$ kategori sangat sempit yaitu kurang dari $500 \mathrm{~m} 2$. Soekartawi (2005) menyatakan bahwa ukuran luasan usahatani selalu berpengaruh positif dengan adopsi inovasi. Banyak teknologi manu dan baru yang memerlukan skala operasi yang besar dan sumberdaya yang tinggi untuk keperluan adopsi inovasi tersebut juga menggunakan teknologi pertanian yang lebih baik akan menghasilkan manfaat ekonomi yang memungkinkan perluasan usahatani selanjutnya.

Jenis jahe yang diusahakan

Tabel 5. Distribusi Frekuensi Jenis Jahe yang diusahakan Responden

\begin{tabular}{llcc}
\hline & Frequency & Percent \\
\hline Valid & Jahe emprit & 20 & 66.7 \\
& Jahe merah & 6 & 20.0 \\
& Jahe gajah & 4 & 13.3 \\
& Total & 30 & 100.0 \\
\hline
\end{tabular}

Sebagian besar responden $66.7 \%$ mengembangkan jahe emprit dikarenakan jahe emprit memiliki aroma sangat tajam dengan kandungan minyak atsiri 1,50 $3,50 \%$, dan banyak digunakan sebagai bahan obat herbal, banyak diminati konsumen (banyak yang membutuhkan). data harga masing-masing jenis jahe: mana yang harganya lebih tinggi untuk tambahan penjelasan. Bisa jadi misalnya, jahe emprit harga jualnya tidak setinggi jahe gajah, tetapi karena pemasarannya lebih mudah, maka itulah yang dipilih.

\section{Pengolahan Jahe}

Tabel 6. Distribusi Frekuensi Pengolahan jahe

\begin{tabular}{llcc}
\hline & & Frequency & Percent \\
\hline Valid & Jahe instan & 12 & 40 \\
& Belm diolah & 18 & 60 \\
& Total & 30 & 100.0 \\
\hline
\end{tabular}

Sebagian besar responden $60 \%$ belum melakukan pengolahan, dikarenakan petani lebih menginginkan cepet memperoleh uang dengan menjual dalam bentuk rimpang tanpa mengolah terlebih dahulu. Adakah data harga jual segar vs. olahan? Sebagai pembenaran bahwa memang lebih praktis dan "menguntungkan" bagi mereka kalau dijual segar. Sementara kalau diolah, memang menaikkan nilai tambah, tapi profit belum tentu. Alternatif pengolahan lain, semisal sebagai simplisia, dan sebagainya.

Pemasaran Jahe

Tabel 7. Distribusi Frekuensi Pemasaran Jahe

\begin{tabular}{llcc}
\hline & & Frequency & Percent \\
\hline Valid & Pasar tradisional (pengepul) & 17 & 56.7 \\
& Kios (warung) & 6 & 20.0 \\
& Konsumen Langsung & 7 & 23.3 \\
Total & 30 & 100.0 \\
\hline
\end{tabular}


Sebagian besar responden 56,7 \% menjual jahe ke pasar tradisional ke pengepul di tingkat pasar, dikarenakan petani lebih cepat menerima uang dan dalam jumlah banyak pun mau membeli.
Hampir sama dengan yang sebelumnya, Mas. Kalau ada data harga kalau dijual di pasar berapa, kios berapa, konsumen berapa. Untuk lebih menegaskan.

Pengembangan SDM yang pernah dijalani

Tabel 7. Distribusi Frekuensi kegiatan pengembangan SDM yang pernah diikuti

\begin{tabular}{llcc}
\hline & & Frequency & Percent \\
\hline Valid & Penyuluhan, SL & 21 & 70.0 \\
& Belum pernah & 9 & 30.0 \\
& Total & 30 & 100.0 \\
\hline
\end{tabular}

Sebagian besar responden $70.0 \%$ pernah mengikuti kegiatan penyuluhan berupa penyuluhan, SL dan sosialisasi jahe oleh para penyuluh. Menurut mereka manfaatnya apa setelah mengikuti SL, dan sosialisasi jahe? Apakah membantu usaha taninya atau tidak, harapannya bagaimana kedepannya.

Hama dan Penyakit yang menyerang tanaman jahe di Kecamatan prambanan sebagai berikut:

Hama

\section{Lalat Rimpang (Mimegrala coeruleifrons)}

Larva lalat rimpang merusak tanaman jahe yakni menyerang rimpang dengan gejala tanaman menunjukan layu, daun mengering, kemudian jika dicabut dan diperiksa bagian rimpangnya menunjukan warna pucat dan tetap utuh, tetapi jika rimpang dibuka maka bagian dalam terlihat lapuk seperti gumpalan tanah, serangan berat terjadi pada tanaman jahe berumur 5 bulan.

Morfologi lalat rimpang tubuhnya ramping kaki panjang, dan sayap berbelang hitam. Lalat jantan dan betina dapat dibedakan dengan melihat panjang tubuh lalat betina $13,96 \mathrm{~mm}$ dengan rentang sayap $19,56 \mathrm{~mm}$, sedang panjang tubuh lalat jantan 13,71 $\mathrm{mm}$ dengan rentang sayap 19,36 mm. Stadium imago berlangsung 4-6 hari ( Kalshoven, 1981).

Pengendalian lalat rimpang dapat dilakukan dengan memadukan berbagai cara yaitu menggunakan bibit jahe yang sehat, menjaga kebersihan kebun dengan melakukan penyiangan intensif dan jika serangan berat dapat dikendalikan dengan insektisida kimia.

\section{Hama Kepik (Epilahra sp.)}

Kepik menyerang daun tanaman jahe hingga tinggal tulang daun sehingga sangat menghambat pertumbuhan dan mengakibatkan turunnya produktivitas, kemudian serangan pada tanaman muda mengakibatkan kematian tanaman.

Morfologi kepik dewasa berbentuk oval dengan panjang 6-8 $\mathrm{mm}$, warna bervariasi kemerahan dan coklat kekuningan. Kepik betina meletakkan telur pada sisi bawah daun secara berkelompok, 1 kepik betina dapat menghasilkan 12 kelompok telur dan masing masing kelompok berisi 22-50 butir telur. Setelah telur menetas terbentuk larva berwarna kuning pucat dan ditutupi bulu bulu halus dan selanjutnya menggorok dan menggrogoti daun sehingga berlobang( Kalshoven, 1981).

Pengendalian kepik dapat dilakukan dengan menggunakan agensia hayati yaitu Jamur Beauveria bassiana, tidak menanam campuran antara jahe dan kacang panjang, jika serangan berat dilakukan penyemprotan insektisida kimia sesuai dosis anjuran. 
Penyakit

Busuk akar rimpang (Fusarium oxysporum). Penyakit yang menyerang adalah layu yang disebabkan oleh Jamur Fusarium oxysporum dan menimbulkan kerugian besar karena tanaman yang terserang mengalami kematian. Gejala serangan pada daun bawah menguning kemudian seluruh daun layu dan pucuk tanaman mengering.

Jika batang palsu atau akar rimpang tanaman sakit dipotong akan tampak bekas pembuluh berwarna coklat dan pada serangan berat akar rimpang membusuk dan berwarna kehitaman.

Penyebab penyakit adalah jamur patogen dalam tanah (soil born) yaitu Fusarium oxysporum, dengan spora berbentuk seperti bulan sabit, berukuran sangat kecil dan hanya dapat dilihat dengan menggunakan mikroskop (Semangun, 2007 )

Pengendalian dilakukan dengan memadukan berbagai cara yaitu tidak menanam jahe terus menerus pada lahan yang sama, penanaman bibit yang sehat, memberi kompos/ bahan organik yang telah inokulasi/diberi jamur antagonis Trichoderma sp., mencabut tanaman sakit kemudian dibakar dan jika serangan berat dikendalikan dengan fungisida kimia sesuai dosis anjuran (Heriyanto, 2017)

Bakteri

Penyakit layu bakteri menyerang tanaman melalui luka akar kemudian terikut aliran air masuk kedalam pembuluh/jaringan pengangkutan yang lama kelamaan menimbulkan koloni yang terdiri dari masa bakteri dan akhirnya transportasi air dari akar ke organ daun sangat terhambat bahkan berhenti. Gejala yang tampak terutama pada daun dewasa adalah tumbuh dengan tepi melengkung ke bawah tampak seperti kekurangan air , berwarna hijau kusam kemudian menguning, selanjutnya secara mendadak tanaman menjadi layu, kemudian daun mengering dan tanaman rebah.
Rimpang yang terserang penyakit bakteri jika dipotong dan dilembabkan akan keluar cairan berwarna putih keruh yang sebenarnya adalah kumpulan masa bakteri, sehingga cara ini dapat digunakan untuk mengidentifikasi penyebab penyakit dilapangan dan membedakan dengan penyakit lain (Barnete H.L - B.B. Hunter, 1972; Tuite.j.1969)

Pengendalian penyakit bakteri dilakukan dengan cara kultur teknis, kemudian pada lubang tanam / tanah sekitar pangkal batang ditaburi jamur Trichoderma sp yang merupakan agen hayati bersifat antagonis. Jika serangan berat pengendalian dengan bakterisida yang memiliki bahan aktif tetrasiklin atau lainnya.

Pengendalian dengan cara isolasi yaitu memberi tanda pada tempat tanaman yang menunjukan serangan penyakit dengan gejala layu, kemudian tanaman yang terserang dibongkar dan dibuat parit keliling dengan jarak pada 1 rumpun dari tanaman sakit, kemudian tanah galian dibuang ke area dalam yang sudah dikelilingi parit dengan maksud untuk mengisolasi. Selanjutnya tanam sakit dicabut dan dibakar, bekas lubang tanaman sakit dibongkar dan dikelantang agar terkena sinar matahari.

\section{SIMPULAN DAN SARAN}

Kesimpulan dari hasil penelitian dapat disimpulkan sebagi berikut:

1. Hama yang menyerang lalat rimpang (Mimegrala coeruleifrons), hama kepik (Epilahra sp.) dan penyakit yang menyerang busuk akar rimpang (Fusarium oxysporum) Penyakit layu bakteri.

2. Pengolahan hasil jahe yang sudah dilakukan petani $60 \%$ belum dilakukan pengolahan.

3. Pemasaran jahe yang sudah dilakukan petani $56.7 \%$ dipasarkan di pasar tradisional. 
4. Pengembangan SDM petani $70 \%$ melalui penyuluhan (SL dan Pertemuan) penelitian melalui pengamatan budidaya jahe di Kecamatan Prambanan dapat dikembangkan.

Saran

1. Dilakukan pengamatan OPT secara rutin.

2. Perlu dilakukan penganekaragaman bentuk olahan tidak hanya jahe instan.

3. Perlu melakukan pemasaran secara online (alternative moda pemasaran yang mengikuti perkembangan zaman saat ini?)

4. Penyuluhan dengan materi aneka macam olahan jahe dan pemasaran jahe secara online.

\section{PUSTAKA ACUAN}

Badan Pusat Statistik Kabupaten Sleman. (2017). Kecamatan Prambanan dalam Angka Tahun 2017. Sleman : Badan Pusat Statistik.

Balai Pengkajian Teknologi Pertanian (BPTP) Sumatera Utara. (2012). Petunjuk Teknis Budidaya Jahe. Medan, $45 \mathrm{p}$.

Barnett. H. L. and B.B. Hunter. (1972). Illustrated Genera of Imperfect Fungi. Burgess Publishing Company. Minneapolis United States of America, 241p

Cooke, T. D., Persley and S. House. (2010). Diseases of Fruit Crops in Australia. CSIRO Publishing. Oxford street. Colling wood VIC. Australia, 276 pages.

Dinas Pertanian Daerah Istimewa Yogyakarta. (2015). Teknis Budidaya Tanaman Biofarmaka Yang Baik Mengacu Ketentuan Good Agriculture Practices, Yogyakarta, $26 \mathrm{p}$.

Departemen Pertanian. (2007). Modul Identifikasi Potensi Wilayah dan Agroekosistem Berorientasi Agribisnis. Badan Pengembangan SDM Pertanian. Sekolah Tinggi
Penyuluhan Pertanian.

Dinas Pertanian, Pangan dan Perikanan Kabupaten Sleman. (2018). Programa Penyuluhan Pertanian UPT BP4 Wilayah VIII. Sleman: Dinas pertanian, Pangan dan Perikanan.

Dinas Pertanian, Pangan dan Perikanan Kabupaten Sleman. (2017). Programa Penyuluhan Pertanian UPT BP4 Wilayah VIII. Sleman: Dinas pertanian, Pangan dan Perikanan.

Farry B. P, Murhananto. (2007). Budidaya, Pengolahan, Perdagangan Jahe. Jakarta: Penebar Swadaya.

Haryoto. (1998). Sirup Jahe. Yogyakarta: Penerbit Kanisius.

Hariana, H. Arief. (2015). 262 Tumbuhan Obat dan Khasiatnya. Jakarta: Penebar Swadaya.

Heriyanto. (2017). Pengendalian Penyakit Rebah Semai dengan Trichoderma sp. dan Rhizobakteri Pada Bayam Cabut. Jurnal Ilmu Ilmu Pertanian Sekolah Tinggi Penyuluhan Pertanian Magelang Jurusan Penyuluhan Pertanian Yogyakarta. Vol. 24 (1): 1021

Iskandar, S. A, Daryanto, A, Nurrochmat, D. R. (2016). Strategi Pemasaran Produk Olahan Jahe Merah (Studi Kasus Pada PT. Performa Qualita Mandiri). Program Studi Manajemen Bisnis, Sekolah Bisnis Institut Pertanian Bogor (IPB)

Lamb, C. W, J. F. Hair dan C. McDaniel. (2010). Pemasaran. Jakarta: Salemba Empat.

Majdi, Udo Yamin Efendi. (2007). Quranic Quotient. Jakarta: Qultum Media.

Muharjoa. (2019). Budidaya Tanaman Jahe. Balai Besar Pelatihan Lembang. http://www.bbpplembang.info/index.php/arsip/artikel/a rtikel-pertanian/518-budidaya-jahe diakses 2 Mei 2019.

Prihadhi, E. K. (2004). My Potensi. Jakarta: Elex Media Komputindo.

Prastiyo, A., Fathoni, A., Malik, D. (2018). 
Strategi Pemasaran Produk Jahe Merah Melalui Analisis SWOT pada Perusahaan UD. Barokah Ungaran. Jurusan Manajemen Fakultas Ekonomika dan Bisnis Universitas Pandanaran Semarang.

Sadono, Dwi. (2008). Pemberdayaan Petani: Paradigma Baru Penyuluhan Pertanian di Indonesia. Jurnal Penyuluhan. IPB. Maret 2008, Vol. 4 No.1

Saparinto, C. dan R. Susiana. (2016). Grow Your Own Medical Plant. Panduan Praktis Menanam 51 Tanaman Obat Populer di Pekarangan. Yogyakarta: Lily Publisher.

Slamet, M. (2001). Paradigma Baru Penyuluhan Pertanian di Era Otonomi Daerah dalam I. Yustina dan A.
Sudradjat (eds). 2003. Membentuk Pola Perilaku Manusia Pembangunan: Didedikasikan kepada Prof. Dr. H. R. Margono Slamet. Bogor: IPB Press.

Sugiyono. (2009). Metode Penelitian Kuantitatif, Kualitatif dan R\&D. Bandung : Alfabeta.

Tjiptono, F. (2012). Pemasaran Strategik. Yogyakarta: Andi Offset.

Undang-Undang Republik Indonesia Nomor 16 tahun 2006 tentang Sistem Penyuluhan Pertanian, Perikanan dan Kehutanan.

Yunarni. (2010). Teknologi Pengolahan Dan Pengawetan Jahe Sebagai Keterampilan Guru SMK dalam Upaya Mengembangkan Kewirausahaan Sekolah. FT Universitas Negeri Yogyakarta.

DOI : 